\title{
Die deuntjie draal': \\ Op die spoor van Koos du Plessis
}

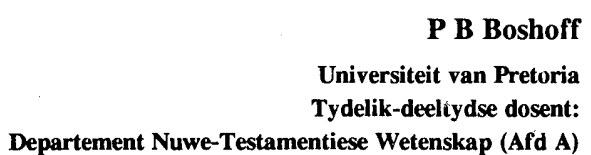

\begin{abstract}
'The melody lingers on': On the trail of Koos du Plessis

The angst experienced by $D u$ Plessis assumes the form of a problem on which he ponders in his poetry. The questions that he poses differ in form only from the bewilderment experienced by the naive. The poetic art of the singer and the faltering intimations of the despondent heart are two languages that express the same human anxiety. The truth of both languages lies therein that the one can develop into the other. This article listens from a Christian viewpoint. Themes that are dealt with are wandering, the goldy Other, past and future, anxiety, waiting, dreaming and temptation.
\end{abstract}

\section{INLEIDING}

Dit kan seker nie vreemd wees dat 'n predikant 'n digter se werk lees of na iemand se liedere luister nie. Die kerk sing ook sy liedere en 'n predikant hou hom voortdurend besig met die lees van tekste. In die kerklike liedere en tekste word die gelowige se bestaan as mens verwoord. In ander liedere of tekste word weer 'n bepaalde siening van die menslike lewe onder woorde gebring en die teoloog is geïnteresseerd in die verduideliking van die lewe wat daarin gegee word. Veral wanneer die tekste nog jonk is en nog nie deur interpretasies oorwoeker is nie, stel dit 'n nuwe uitdaging aan die geduldige leser. In die geval van Du Plessis het die tekste nog die bykomende voordeel vir 'n predikant dat hy hier met die vaster tred van sy moedertaal kan beweeg, al moet hy die gegewene in ' $n$ verstaanbare taal vir homself vertaal. Sy aandag sal hoofsaaklik toegespits wees op die lewensverstaan wat in die tekste uitgedruk word en nie soseer op die kunstigheid van die gedig of die woord-toonverhouding van die lied nie.

Vir sowel die predikant as die digter gaan dit om die menslike eksistensie; dit vorm die gemeenskaplike grond tussen hulle. Die digter word gelees omdat sy skryfwerk getuig van egte besinning oor die mens se lewe. Wat die digter sê, word in verband gebring met die Christelike selfverstaan van die mens. Du Plessis self het daarmee rekening gehou dat daar iets konstants in sy werk verdig word wat verder gelees sal word: 
As dit gedaan is, en verby, die aarde weer sy erfdeel kry, sal hierdie kluisenaar in my nog iewers in 'n boekrak bly.

(sonder 'n titel, 1985:16)

In 'Briefie uit die see' sien du Plessis (1988:71) homself ook as die ontvanger en aangeër van 'n tipiese boodskap. In 'briefie uit 'n verre land' vertel hy van sy 'hartsgeheime, wel en wee.' Wat hy ontvang het, gee hy verder aan en na hom sal iemand 'ure sit en droom met/die vreemde briefie in sy hand'. Die lang ketting van vertellers verhinder nie dat die boodskap verstaanbaar bly nie: die deuntjie draal.

Die interpretasie wat hiermee aangebied word, het oor 'n tydperk vorm aangeneem. Heelwat hersiening is gedoen en veranderings aan vroeëre standpunte is aangebring. Op sigself is die uitgooi van agterhaalde menings nog nie 'n waarborg dat die saak hierdie keer reg benader word nie, maar miskien kan dit as 'n aanbeveling dien vir wat die leser in sy hand kry.

\section{SWERWER}

Dat die digter kluisenaar is en hom nie werklik verbind aan die gesellige verkeer van mense nie, distansieer hom van die res en dui daarop dat hy die grens van dit wat gewoon menslik is, oorgesteek het. Hy neem liewer van die oppervlakkige gesellige verkeer afskeid, as om hom daarby te laat insleep:

Alle sterkte en, onthou daar's krag na kruis.

Kom weer kuier en sê groete by die huis.

Ons hou almal duim vas. Kom tog veilig tuis.

Doen jou plig en eendag sal jy almal wys.

Dis alles woorde -

net leë woorde -

op vals akkoorde;

en almal sing dit, almal sing, ja, almal sing dit saam.

Vaarwel.

(Woorde, 1988:19) 
Sy ervarings as eensame mens kan 'n ongewone skerp lig werp op die noodsaaklike voorwaardes vir die menslike bestaanswyse. Hy beskryf homself as swerwer (Du Plessis 1985:9, 42, 50; vgl 1988:69) by wie die onrus wakker bly omdat hy die geborgenheid van 'n huis en die terugkeer daarheen, moet ontbeer. Vir hom het die 'huis-toe-pad' 'n 'dood-loop-pad' geword (Du Plessis 1988:45):

En waar ek nou oor geel papier gekrom tuur na die los gedagtes van jou hand weet ek dat elke goedgekose woord 'n hek is op my lang-lang pad terug; dat elke sin 'n wag is voor 'n poort en elke punt 'n weggespoelde brug.

En duisend silwer somernagte saam sterf met die laaste kartel van jou naam.

(Dagboek van 'n swerwer [2], 1985:42)

Die mens wat egter lank genoeg van die basiese menslikheid van 'n huis en die menslike verhoudinge weerhou word, boet naderhand 'n deel van sy gevoelslewe in. Du Plessis beskryf dit as die uiteindelike doodgaan van die hart:

Uiteindelik het ons dít geërf:

twee deurgeloopte sole

en 'n hart wat stil-stil sterf

aan konka-kroep oor konka-kole.

(Swerfporsie, 1985:50)

Die kwynende swerwer vorm deur sy figuur ook kommentaar op die gemeenskap. Waar hy sterf van verlange na menslike warmte, kan die gemeenskap nie onaangeraak bly nie en is sy ondergang naby.

\section{DIE RAAISEL VAN DIE LEWE}

Die aartsvader Jakob het by die Jabbokdrif vir sy nagtelike teenstander gevra: 'Sê my tog jou naam' (Gen 32:29), en as antwoord 'n teenvraag gekry: 'Waarom vra jy my 
naam?' En 'n mens kan jou voorstel dat dié antwoord hom nie bevredig het nie. In dieselfde menslike frustrasie van om nie-te-weet-nie, deel Du Plessis en verwoord dit in die gedig 'Dwaalspoor' (1985:14):

So baie, baie keer het ek jou vreemde naam vergeefs vir kroegman, klerk en predikant gespel en daar was so baie leë winternagte saam met mense wat nie weet waarheen nie, maar vertel.

(Dwaalspoor, 1985:14)

'n Deel van die onvergenoegdheid is dat 'n mens ook nie vertroue het in iemand wat alte seker is en uit 'n ongerepte geloof, 'n maklike antwoord op sy vrae gee nie. Die ongeloofwaardigheid van 'n maklike antwoord wat remand anders gee, hoef egter nie sonder 'n positiewe kant te wees nie, want dit kan die aantrekkingskrag wat die 'vreemde naam' nogtans uitoefen, net nog meer beklemtoon. Die.twyfelaar doen voorlopig afstand van 'n sekerheid, maar met die bedoeling om dit later te verwerf, en dit en dan des te sekerder te hê. Hy wil nie 'n naprater wees nie, maar die naam self nuut uitspreek. Vir eers weet hy net dat dit 'n vreemdeling is wat by hom sal bly. Hoewel daar so 'n soort metodiese twyfel kan wees, waarin die onsekerheid 'n deel uitmaak van die lang pad na groter duidelikheid, laat 'n verklaring in hierdie rigting nie reg aan hierdie teks geskied nie. Die 'nou' beteken nie 'vir eers' nie, maar dui op 'n gevolgtrekking waartoe hy gekom het: Die onsekerheid is nie net 'n deurgangstadium nie; dit sal hom altyd vergesel:

Nou weet ek net jy sal my steeds gevange hou.

Want wie is jy? En waarom soek ek so na jou?

(Dwaalspoor 1985:14)

Die gewone menslike optrede is dat hy nie van die raaiselagtigheid van die lewe en die dood hou nie en daaraan probeer verbystuur. Die geheimenisvolle bevraagteken hom en stel grense aan sy selfbeskikkingsmag en daarom wil hy van so 'n verontrusting af wegkom. Du Plessis se woorde gee egter blyke van die besef dat daar 'n laaste geheim om elke mens hang wat nie net sy eie is nie, wat hy self nie alleen kan opklaar nie. Hy aanvaar hierdie onrustigheid wat dit meebring. Die onthulling van hierdie geheim is nie in die mens se eie mag nie en só geskied dat dit op 'n dag duidelik word dat alles 
mooi netjies só en só inmekaarpas nie. Die vraag is of die mens die bereidheid kan volhou om hierdie geheim te bewaar en daarin te lewe. Kan die mens dit verdra dat die geheim 'n geheim bly, dat hy nie oor homself beskik nie? Want om deur hierdie geheim geboei te wees, moet die mens homself stel onder die onrus wat dit meebring. Die mens is tegelyk geboei, 'n gevangene van die raaiselagtigheid, verwonderd daaroor en hy het die onrus dat hy op ' $n$ dwaalspoor is en geen toegang kan kry nie. In geleerde taal word die onrus tremendum en die boeiende fascinosum genoem.

Du Plessis noem nie die raaiselagtige, irrasionele numineuse God nie en ons moet dit ook nie doen nie. Dit is nog maar net die raaiselagtige en dit laat die digter tereg voel dat hy aan die dwaal is. Op sy vrae kry hy nie 'n antwoord nie. Die vreemde naam kry hy nie gesê of gehoor nie, en dit bly net by spelling. Ofskoon die spelling geen $\sin$ sal hê, as dit nie naderhand 'n naam skryf nie: die geheim sal sy sin verloor as dit nie ook gaan om wat daaragter lê nie. Daarom bely die digter sy soeke: 'soek ek so na jou'. Daarmee gee die gedig die struktuur aan die moontlikheid van geloof. Want die Christelike geloof vertolk die mens se soeke, sy dwaalspoor as uitdrukking van sy verlange om op die regte pad gelei te word, sy hoop om gevind te word. Want eers wanneer hy gevind word, weet die verdwaalde waarna hy gesoek het. Eers uit die antwoord van die evangelie leer die mens sy verkeerde vrae af en sy eie ware vraag na heil ken. Vir die mens wat na homself, sy identiteit, sy heil soek is die eintlike antwoord die evangelie en die ware verdwaalde kan hierin uiteindelik tuiskom. Sonder die antwoord sal dit 'n vrugtelose soektog bly, want die geheim lê daarin dat die waarheid van die menselewe verborge is en openbaar gemaak moet word. Uit homself weet die mens dit nie en bly dit verborge. Hy is afhanklik van die Ander, Vreemde, Onbekende om Homself mee te deel. Hy is van die boodskap afhanklik, want geloof is gehoorsaamheid en nie die ervaring van die irrasionele nie. Die Vreemde kan hom tegemoet kom deur te sê: 'Moenie vrees nie, dit is Ek! Ek is die Een wat jou gevange hou, maar Ek het ook vir jou gesterf en opgestaan. Jou moontlikheid met My saam is oordeel en genade'. As dit die geheim is, is dit tegelyk geheim en openbaar. Die Een wat sy Naam nie aan Jakob wou gee nie het hom nogtans 'net daar geseën' (Gen 32:29). Wie Hy is, weet die mens nie, maar wat Hy doen, kan ons goed verstaan.

Du Plessis spreek nie net direk tot die irrasionele nie, maar rig hom ook tot sy medemens wat na geluk en geborgenheid soek. Hy noem die geluksoeker "n stadskind' en daarmee vat hy die tweepoligheid van die mens saam: As kind is hy toeganklik vir 'geluk en vreugde', maar as stedeling is hy ver van sy oorspronge af verwyderd. Met 'n 'sprokie' wil die verteller die kind nader aan die geheimnisvolle bring en vooruitgryp na die toekomstige heelheid van die lewe en wêreld. Die mens moet egter nie dink dat hy die versadigingspunt bereik het nie; so 'n sekerheid is daar nie: 
Maar hier moet jy jou nimmer laat bind, want so lui die ou-ou sprokie, my kind:

As jy geluk en vreugde wil vind, soek die neonboog se punt.

(Sprokie vir 'n stadskind, 1988:5)

Die ou aansporing van die aanhouer wat sal wen, word nie in hierdie sprokie gemaak nie. Aanhou en uithou is nog nie 'n waarborg dat die teenstand sal wyk en die soeker sy skat sal vind en sy beloning kry nie:

Volg hom elke nag oor swart riviere; oor kranse van beton; as jy aanhou stap, tienduisend ure, sal jy dalk daar kom.

Die hemel bly sonder sterre en dit is maar net 'n 'neonboog' wat gevolg word. Daarom is die verteller se belofte van ' $n$ beter bedeling nie definitief nie, maar net miskien:

Dalk vind jy die land van blou saffiere ... en dalk ' $n$ brokkie son.

(Sprokie vir 'n stadskind, 1988:5)

Die 'land van blou saffiere ...' het myns insiens 'n literêre meerwaarde. In Eksodus 24:10 staan ' $(\mathrm{H})$ ulle het die God van Israel gesien: onder sy voete was 'n plaveisel soos saffiersteen, so blou soos die hemel self' (vgl Jes 54:11; Op 21:19). In die lied word daar na 'n klimaks toe gewerk deur eers die 'skatkis', daarna 'geluk en vreugde' en as hoogtepunt 'die land van blou saffiere ...,' in die vooruitsig te stel. Die geheel wat die sprokieverteller in gedagte het, is waar mens en God versoen is. Staan dit regtig in die teks, of het ek dit daar ingelees?

'n Ander moontlikheid om bestendigheid van buite en vreugde van binne te verkry, is om in die verlede in terug te gaan:

Hier oor die stad hang bleek die oggendmis, en droë winde soek langs skemer strate na wat onvindbaar is. 
En hoog in grou geboue, deur die glas, staar moeë oë oor die grys woestyn

en peins oor dit wat was.

(Winteroggend, 1985:49)

Dit lei ons na die digter se kinderjare:

\section{VERLEDE EN TOEKOMS}

Du Plessis gryp terug na die geborgenheid en veiligheid van sy kinderjare:

Daar was 'n huis met 'n kombuis en greinhouttafel en ses mense het gedeel in lief en leed ...

(Molberge [herinneringe aan Springs], 1988:51)

Maar die grense van hierdie vertroude wêreld is nie veilig nie, die radeloosheid en verlorenheid breek deur en vereensaam die mens: 'En mettertyd het alles uitgerafel'. Die herinnering bly nog, want die volkomenheid van die geborge kinderlewe word 'n oerbeeld van ' $n$ ware menselewe en daarom lees ons as refrein in dieselfde gedig 'Ek onthou'. Die herinnering moet die ou verlore vastigheid in die hede weer werklikheid laat word. Maar die verlies is onherroeplik, selfs die kragtoer van die herinnering kan niks daaraan verander nie. Die digter weet en erken dat daar groot skade gekom het:

en droom en bou al vreet die vrees die vrede en al is my eie wêreld halfpad hol.

(Molberge, 1988:51)

Die sanger beskryf die mense as 'soekers wat nooit vind ...' (Kinders van die wind, 1988:3). Die mens is soekend, want hy het eenmaal iets van die werklikheid van geborgenheid beleef of minstens ' $n$ vermoede gehad van waar dit te vind is, maar dit is nou 'n verlore land en op geen manier kom hy meer tot sekerheid nie. Die struikelblok waaroor hy nie kan kom nie, is die gedagte dat die ou vrede in die hart nie verder as die vergane oomblik strek nie. Die waarde vir die hede van dit wat hy eens ervaar het, kan hy nie met sekerheid vasstel nie. Wat eens so seker was, het nou vreemd geword. Hy voel die gemis aan leiding sterk aan, want die mens se lewe is in beginsel onvoltooid, gekenmerk deur onderweg-wees. Hy is soos 'n kind wat reggehelp wil en moet word, maar die hulp daag nie op nie: 
Tog vreemd die tyd se laaie.

Die lewe te bitter kort.

Dat ons, ná al ons paaie, iedereen

weer kind, maar wéés, moet word.

(Onthou jy nog?, 1988:37)

Ook die taal, wat nie bloot 'n instrument is nie, maar 'n geestelike lewensruimte aangee, ' $n$ horison waarbinne ' $n$ mens met vertroue kan beweeg, ' $n$ band met die ervaring van voorgeslagte vorm, laat die sanger in die steek:

Gesigte, drome, name, is deur die wind verwaai;

en waarheen al die woorde is, sou net ' $n$ kind wou raai.

(Kinders van die wind, 1988:3)

Ook die verte waarin die digter gevolg wil word:

As jy my kon volg op die vleuels van die wind, na wêrelde oorkant die maan, sou jy my spoor in die melkweg vind, my tent tussen sterre sien staan ...

$$
\text { (As jy my kon volg..., 1988:9) }
$$

Dit het eksistensiële betekenis; dit dui nie net bloot afstand aan nie. Die verte staan vir wat nog moet kom. In die verte soek hy na sy verlore tuiste. Die nabyheid ontglip hom en die verte lok hom. Hy is uitgegooi uit sy oorspronklike sekerheid en vertroude wêreld en maak daarop staat dat die oorkantste wêrelde hom kan herberg.

Die verte, wat in die digter self geleë is, sou met liefde gevul kon word:

As jy my kon liefhê tot alles vergaan

en nooit ooit die skeiding sou vrees, sou ons die lewe kon leer verstaan 'n oomblik gelukkig kon wees. 
In 'n byna apokaliptiese voorstelling stel hy dat die ou wêreld se tyd verby is en dat die nuwe bedeling met die liefde kom. Nietemin betwyfel hy die aanslag van die liefde, want alle vorige pogings het misluk:

Maar ons is nog jonk en die wêreld is oud;

en voor ons het almal gefaal.

Neem nou my hand, want die nag is koud -

dis dalk die heel laaste maal.

In 'Skadu's teen die muur' (1988:11) word beskryf hoe die verlede 'die tafel en die laaikas', die toekoms 'drome', die hede 'liefde' en samevattend 'die lewe' skadu's word. Sy eie bestaan word ook onwaarskynlik. Die slotvers oor die sinloosheid lui:

Die donker kom van buite

en syfer deur die ruite

en ek gooi nog 'n paar kole op die vuur.

En my voet en my hande

word ou bekende lande

in skadukaarte teen die kamermuur.

Die wêreld word 'n skadu teen die muur;

'n flikkerende skadu teen die muur.

Die benoudheid wat ' $n$ mens by die besef van die sinloosheid oorval, kan met niks verdryf word nie. Die kole verdryf nie die donker nie, maar help om die skadu's te vorm. Die Christelike boodskap ontken nie die mag van die sinloosheid nie en roep ook nie die mens op om self die stryd daarteen aan te pak nie. Dit verkondig dat God sy mag gebreek het en dat hy sy mag nog net kan laat geld oor mense wat hom die geleentheid daartoe gee: 'In die wêreld sal julle dit moeilik hê; maar hou moed: Ek het die wêreld klaar oorwin' (Joh 16:33).

\section{ANGS}

In 'As almal ver is' gee Du Plessis 'n aanduiding van die toestand van angs. Die geestelike eensaamheid laat hom 'n opname maak van wat hy het en waarop hy sy lewe kan bou en die slotsom waartoe hy kom, is dat sy vermoede bevestig word, naamlik dat hy niks en niemand het nie: 
As daar geeneen is, sit jy al's op die skaal, want jy weet: wat geleen is, word eind'lik gehaal.

Dan kom die waarheid en besweer elke leuen; skenk jou weer klaarheid en laat jou alleen.

(As almal ver is, 1988:47)

Die leuen waaronder ' $n$ mens sy vrees kan verberg, kan wees dat hy vashou aan verbygaande en verbrokkelende waardes, soos die krag van 'n sterk karakter, of 'n buitengewone talent. Maar die waarheid onthul die onsekerheid en breekbaarheid daarvan. Vir die menslike skouers word die las te swaar, want hy moet alles dra, sonder dat hy self gedra word. En wanneer die mens hierdie insig bereik het en hy in hierdie sin by die einde van die wêreld gekom het, is hy nie meer gevrywaar van die ontmoeting met homself nie. Die spieël lig die sluier oor wat nog verborge was:

As almal ver is, vind jy jouself

waar jy in laaie in stil hartkamers delf.

As almal ver is, vind jy jou siel -

weerloos en eensaam, soos 'n vrou voor 'n spieël.

(As almal ver is, 1988:47)

By hierdie kritiese selfontmoeting wil die mens 'n antwoord hê op sy vraag na die sin van die lewe, maar die delf in eie dieptes lewer nie die gevraagde resultaat op nie. Die mens besef sy eie weerloosheid en eensaamheid. Die weerstand wat hy teen die vernietiging kan bied, is maar effens. So stel Du Plessis sy ervaring van die verderf:

Verbasend hoe die lewe

uit almal álles kerf,

tot al wat oorbly bene is -

klein weerstand teen verderf.

(sonder 'n titel, 1985:40) 
Aan die kruis het Christus die verderf sien kom en uitgeroep: 'My God, my God, waarom het U my verlaat?' (Mark 15:34). Volgens die Christelike opvatting open die werklike ervaring van angs die moontlikheid tot vryheid, naamlik vir dié wat die weerloosheid so ervaar dat hulle ook weet van die boodskap: 'maar hou moed: Ek het die wêreld klaar oorwin' (Joh 16:33). Deur die lyding van Christus word die mens tot die kennis van homself gelei. In Christus aan die kruis sien hy hoe nederig hy self eintlik is: 'as ek swak is, is ek sterk' (2 Kor 12:10). Die klagte 'waarom het U my verlaat?' gee in eksistensiële sin die sekerheid van die verlossing, want in die gesug word dit duidelik dat die mens sy lewe verspeel en gee dit indirek uiting aan die hoop op 'n ware lewe. Juis in sy verlatenheid kan die gelowige hom op 'my God' beroep, want dit is God wat in sy lewe ontbreek. Die geloof laat die mens nie toe om die 'my God' te verswyg nie en hou vas aan die woord waarin God sê dat Hy Hom oor mense ontferm. Die weerlose vertrou homself aan God toe en aanvaar homself as 'n geskenk uit die hand van God. Van sy kant af word God se aandag op 'n besondere wyse getrek deur mense wat eintlik geen ander aanspraak het, as dat Hy Hom oor die hulpeloses ontferm nie; mense wat soos volg geteken word:

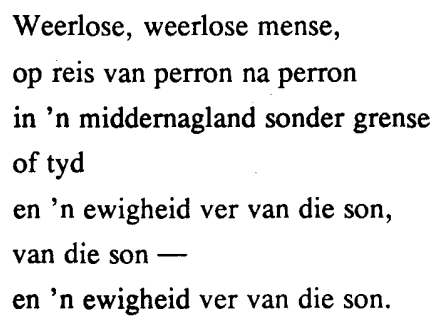

(Skimme, 1988:35)

Hierdie wanhopigheid is die nou poort wat deurgaan na die wye ruimte van geborgenheid. Du Plessis dwing 'n mens egter ook om te vra na wat dan gebeur as daar nie 'n deurgaan deur die nou poort is nie? Wat gebeur as die 'my God' nie geroep word nie en die hoop weggewys word; die stilte die hoop buitehou? In Bybelse taal word gesê dat daar verharding intree. Volgens my gevoel is daar ook geen heldhaftigheid in die lied 'Skielik is jy vry' (1988:17) nie; hy probeer eerder om van die nood van sy ondraaglike eensaamheid, 'n deug te maak. Die woord 'skielik' dra ook 'n onheilspellende toon oor. Wat so eenvoudig begin, het gou ernstig geword. Die verantwoordingloosheid wat hy beskryf, gee uitdrukking aan 'n lewensleegte of verharding: 
Dis tog so eenvoudig:

dis jy, alleenlik jy,

en die groter sorge

gaan vanself verby.

Niks om te verhaal nie,

net die vrede bly.

Niks om te betaal nie -

en skielik is jy vry.

Die mens kom op sy eie bene te staan en is aan die angs uitgelewer. Die digter aanvaar die angs en beskryf hoe dit hom geleidelik vernietig. Die uitklophou word egter nie geplant nie en hy kry kans om te 'dink aan die soeter wyn teen die groter dors' (Kouevuur, 1988:31):

Die kole gloei soos vroëe aande, maar die vuur is in my kop;

en 'n ysige wind skroei my hande vas om die beker met dop.

Die ryp is ' $n$ vlam om my voete, maar die koue brand in my bors; en ek drink en ek dink aan die soeter wyn teen die groter dors.

Met 'n koue hart, tot die môre uur, drink ek teen die vuur in my kop en ek voel die koue, ek voel die vuur vreet my stuk-stuk op.

(Kouevuur, 1988:31)

Ook Kierkegaard (1911:16) gebruik die beeld van 'n 'kalte Brand' om die uitmergelende kwelling van die vertwyfeling mee te beskryf. Hy verduidelik dat die vuur koud bly, want iets wat nie-brandbaar is, het begin smeul. Dit kry nie klaar nie, daar kom nie ' $n$ verlossende vernietiging nie. 


\title{
6. WAG
}

In die lied 'Nagwag' (1988:55) beskryf die digter homself as iemand wat in ciie nag op wag is. Maar vir hom is die wag nie ' $n$ verlangende uitsien na die koms van iets of iemand nie, dit gee eerder uitdrukking aan die gevoel dat niks sal gebeur nie:

\author{
Eindelose ure \\ van sterre en van konkavure, \\ van waak en wag ... \\ volkome wag. \\ Maar die dag bly weg; \\ die maan word lood \\ en een-een gaan die sterre dood.
}

Moontlik is die 'eindelose ure', wat driemaal voorkom, 'n opneem en verandering van Totius se tel van die ure, in sy beryming van Psalm 130. As dit nie die geval is nie, kan Totius se teks nogtans help om 'Nagwag' in perspektief te plaas:

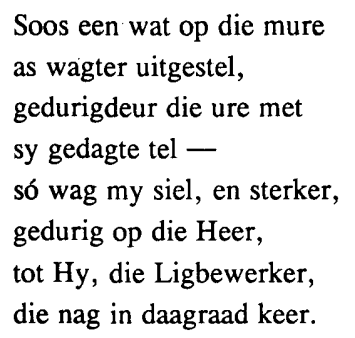

By Totius, met die aftel van die ure, druk die tydsaspek die sekerheid uit dat die dag vir die sanger sal deurbreek. Die wag het hier 'n verwagting geword waarin dit vasstaan dat dit wat genoem word, tevoorskyn sal kom. Die wagter reken daarop; hy neem aan dat dit hom te beurt sal val. By Du Plessis, met die dralende ure, stel die tydsaspek die koms van 'n uiteindelike verandering oneindig uit. Die wag is by hom net negatief: niks gebeur nie; niemand kom nie. Die verhouding tussen die een wat wag en die gebeure wat moet plaasvind, is afgebreek; die wag het absoluut geword. Daar is nie meer vertroue in ' $n$ verdere verloop nie. Alles is om ' $t$ ewe. Die 'volkome wag' beteken dat die nagwag hom intussen en vir goed met niks wil inlaat nie. Die verwagting moet plek' gemaak het vir die vertwyfeling wat opkom uit die gebrek aan vertroue in die behoudende kragte van die wêreld en die lewe. 
Die gebruik van die beeld 'wag' ontbreek en daarom ook dit wat ' $n$ mens as vanselfsprekend daarby veronderstel, naamlik die verhouding tot 'n toekomstige gebeurtenis. Dit dui daarop dat Du Plessis die afwesigheid van so 'n verhouding as 'n verlies aanvoel. Dit moes daar gewees het, maar dit daag nie op nie:

\author{
Maar die dag bly weg, \\ die maan word lood \\ en een-een gaan die konkas dood.
}

(Nagwag, 1988:55)

Wat verlore geraak het is die Christelike belydenis. Waar Petrus hom by die wagvure warm gemaak het, en herken is, en Jesus verloën het, en die haan gekraai het, 'verloën' 'n haan 'homself en kraai' by Du Plessis:

en die vuur se gloed verlig nie eens één lyf of gesig nie nie een lyf of gesig nie.

(Nagwag, 1988:55)

Van die nagwag kan nie eers gesê word dat hy, soos Petrus, iemand verloën het nie. Hy voel die verlies so aan dat hy nie kan dink dat hy ooit iets gehad het wat hy kon verloor het nie. Hy het nie self verloën nie, want hy het nooit regtig geken nie. Sy teenswoordige nood is so groot, dat die herinnering aan 'n geborge verlede nie sal help nie.

Maar so 'n wag op die dag wat nie kom nie, is nog nie die slegste wat daar kan wees nie. Juis in sy verwagtingloosheid het dit die diep besef dat daar 'n verwagting moet wees. Die situasie van 'wag' vra na 'n verwagting. 'n Werklike verwagting kan in hierdie nagwag iemand vind wat vir hom ontvanklik geraak het. Indien die voorafgaande uitleg dat die digter op die verlies van die Christelike belydenis sinspeel, waar is, sou die herstel van die skade, volgens hom, ten minste iets soortgelyks moet wees; die verwagting sal die stempel van God self moet dra. En daar was amper vir hom hoopvolle oomblikke: 
Die nag is net toe deure, gegrendel en gesluit, en hoop klop soveel kere, maar die stilte hou hom uit ... ek wéét.

(Herbergier, 1988:63)

Maar die swaarmoedige stilte sluit hom van die hoop af. Hy is geen strydende figuur meer nie. En dit moet na homself wees na wie die digter terugkyk:

Jy't gekom -

nameloos stom -

en niks geweet

en niks verwag nie.

Dis beter so.

Nooit sal die lewe meer wees

as dié wind-deurwaaide nag

nie.

(Geboorte, 1985:56)

\section{DROOM}

Dit is duidelik dat sy waaksaamheid nie die opgewerkte vlak van op-en-wakker-wees bereik nie. Hy is nie senuweeagtig en op sy eie voordeel bedag nie. Iemand wat so op en aan die gang is, kan nie toegee dat sy kop nou en dan knik nie, soos Du Plessis wel doen:

As iemand tóg sou kom, iewers in die laaste waak wanneer die dief slaap soos 'n kind, laat hom my, dubbel dom kopknikkend van die vaak maar wakker by my konka vind.

(Naglied, 1985:59) 
Hierdie waaksaamheid lê dieper as die oppervlakte en dit het 'n rustige aard. In die helder wakkerwees bly die mens op homself aangewese, maar in die kopknikkende wakkerwees is hy op iemand anders aangewese. Hy is bedag op 'n ontmoeting waarin oor sy lewe beslis word. Hy besef dat die waarheid oor sy lewe van buite moet kom en hy hou hom gereed om met volle oorgawe op die ontmoeting te reageer.

Nou verwant aan sy vakerige waaksaamheid is Du Plessis se dromerigheid. Vir hom bied die droom ' $n$ verskansing teen die gejaagde lewe in die mate waarin dit 'n versameling van lewenskragte in die binneste van die mens vorm. Die dromer raak weg onder die oppervlakte om orde in sy lewe te bring:

Ek hoor nog somtyds stemme in die môre -

'n fluistering van vreemdes uit 'n vér, verlore nag -

en langsaam word 'n oerdroom weergebore

in skemerings van skimme teen 'n skemerende dag;

'n nuwe lig; 'n vergesig:

Iewers is daar nog ' $n$ plek van vrede;

iewers is daar aan 'n wilde kus

'n oord van rus -

iewers in ' $n$ land van lank gelede,

waar alles oud en onveranderd is.

Elke dag beloof 'n nuwe hawe:

telkens is daar vaste grond in sig

in oggendlig.

Elke aand word elke droom,

maar dan, een môre, keer die stemme t'rug;

sien ek, met die oë omhoog gerig,

'n visioen, 'n vergesig:

'n sterrebrug!

'n land van lig!

(Stemme in die môre, 1988:39)

Die dromer is gewoonlik nie die mens wat vormgewend in sy lewe ingryp nie, hy wil eerder 'n ontvanger wees, want die droom, die vergesig, die land van lig word aan hom geskenk. Iemand wat tot die uiterste beproef word, spreek in hierdie gedig sy behoefte 
aan 'n visionêre deurbraak uit. Die visioen moet vir hom 'n persoonlike genadebewys bring. 'n Mens kan aanvaar dat die hoop op 'n mistieke ervaring van God Du Plessis vir 'n tydlank gedra het. Teenoor hierdie hoop moet opgemerk word dat om die droom as ' $n$ metode te gebruik, nie werklik passief is nie, maar hoogs aktief. 'n Kort herinnering aan die aartsvader Jakob kan ook hier van hulp wees: Toe hy wakker was het hy en sy op-en-wakker ma, Rebekka op 'n slinkse manier die seën van Isak ingepalm. Maar ' $n$ mens wat so maak, kan nie in die beloofde land bly nie; hy moet uit. Hy slaan op die vlug voor sy broer Esau. Maar terwyl hy vlug, raak hy aan die slaap en in 'n droom verskyn die Here aan Hom en belowe sy begeleiding aan Jakob (Gen 28:10-22). Met die belofte van sy begeleiding lê God volkome beslag op Jakob, want hy kan net met ' $n$ onverdeelde hart aan die belofte vashou. Sonder die geloof aan die belofte: 'Ek is by jou en Ek sal jou beskerm waar jy ook al gaan. Ek sal jou na hierdie land toe terugbring. Ek sal jou nie in die steek laat nie. Ek sal doen wat Ek jou beloof het' (Gen 28:15), kan hy nie na die beloofde land toe terugkeer nie. Die 'sterrebrug' van Du Plessis (1988:39), anders as die 'neonboog' (Du Plessis 1988:5), laat 'n mens dink aan die leer wat Jakob gesien het - die leer wat aarde en hemel verbind het. In die digter se geval neem hy egter self die inisiatief om sy werklike self deur 'n bonatuurlike self te vervang. Hy word 'n siener. Die poging om vir homself 'n nuwe bestaan te verwerf, is die uiterste vorm van die mens se soeke na homself. Die stem is Jakob se stem, maar die droom is Du Plessis s'n. In Jakob se geval is dit die aanspraak wat op hom gemaak word, die boodskap - waarvan hy in sy droom die ontvanger is - wat die verskil in sy werklike lewe moet maak. Ook vir die Bybelleser kom daar nie ' $n$ visionêre deurbraak nie, maar sorg die teks vir die deurbraak deurdat dit die goddelike aanspraak en belofte oordra.

\section{AANVEGTING}

Die tweespalt tussen die swẹrwer en die wêreld beskryf 'n dreigende spanning tussen die twee. Enige tyd kan die wêreld toeslaan en die swerwer in 'n onbeskutte weerloosheid agterlaat. Het die wêreld en die lewe die swerwer eindelik oorwin? 'n Mens sou dit verwag, maar dit blyk tog nie die geval te wees nie. Die digter stel hom voor dat hy self op die wenpad is. Solank as wat hy nog nie in die pad geval het weg van sy tuiste af nie, veroorloof hy hom die luukse van die gedagte aan 'n oorwinning wat hy behaal: 
Maar, tot die ryp kraak onder skoene wat geen ander haard of tuiskoms ken, gun ek my nog visioene van een wat die hele wêreld wen.

(Groet sonder woorde, 1988:75)

Maar die droom is as 'n illusie ontmasker. Soos hy wou, kon hy die wêreld nie tem nie. Die hoop wat hy gehad het, moes plek maak vir 'n moedeloosheid wat liewer alles wil vernietig en die lewe self van die hand wys. As hy huis en haard verlaat en die ryp onder sy voete kraak, vernietig hy in 'n uiterste kragsinspanning sy eie bestaan, om sy eie wil teen die dreigende wêreld te handhaaf. Hy verkies die dood bo die onderwerping aan die voorwaardes van die lewe. Hy maak 'n heldhaftige keuse vir die dood:

As niemand my kom haal nie en ek doelbewus die lig verruil vir ryke van die duisternis.

(Aansoek, 1985:63)

Hy meen ook dat sy doodsdrang religieus regverdig kan word en bid:

Eintlik smag ek na $u$ waters van rus.

Lei my, Heer vanaand daarheen.

(Gebed, 1990:20)

As gebed klink dit nie eg nie, daarvoor is dit te berekend. In ander verse word dit duidelik dat $\mathrm{Du}$ Plessis van die Here geen antwoord kry nie. Hier is die digter nie meer soeker, soekend na wat hy eens gehad en verloor het nie, hy is die oortuigde wie se oortuiging aangeval word. Dit was sy aanvegting dat die Here hom nie antwoord nie en dat hy self nie meer 'n antwoord verwag het nie. 'n Aanduiding hiervan kry ons waar hy die begrip wat by hom daag, verwoord:

Dis soms asof ek verstaan:

Hy sien ons vuurtjies vir

sterre aan;

Hy het vergeet,

sy vuur geblus

en weg gegaan.

(Begrip, 1985:58) 
Die digter temper sy alleenheid en troos homself as hy voortgaan:

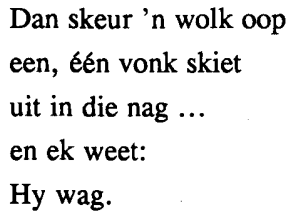

(Begrip, 1985:58)

In hierdie vers word met die stof van Jesaja 64:1-2 gewerk. 'As $U$ maar die hemel wou oopskeur en wou afkom sodat die berge voor $U$ skud! Kom af soos 'n vuur wat fynhoutjies laat brand, soos 'n vuur wat water laat kook'. 'n Opvallende verandering wat $\mathrm{Du}$ Plessis aanbring, is dat hy die profeet se bede dat die Here 'die hemel oopskeur en wou afkom' 'n wete maak dat die Here wag. Dit wek die indruk dat die gevoel van verlatenheid nie so ernstig is nie en by ' $n$ bepaalde punt vanself sou kon omslaan in 'n bewustheid van genade wat tog gereed gehou word. In vergelyking met die profeet verwag die digter minder van die Here self. In plaas van om te kom, laat Hy net 'n vonk skiet en verder wag Hy. Tegelykertyd kom die diger self met meer vorendag as die profeet; die digter 'weet', terwyl die profeet in sy klaaglied om die verwoeste tempel (Jes 63:15-64-11) pleitend bid. Volgens die profetiese teks om die wending vir die verlorenes deurdat hulle hoopvol in gebed na God vra, dat Hy hulle in die dag van benoudheid moet sien en Hom oor hulle ontferm. Deur God met ' $U$ ' aan te spreek word die erkenning gemaak dat daar reeds 'n verhouding tussen God en mens bestaan. God het die begin gemaak. Die mens is al aangespreek en kan die verhouding voortsit en eerbiedig. Die ban van sy godloosheid word gebreek deurdat die mens sy swye verbreek en bid. Die digter vervang egter die waag van die gebed deur die konsentrasie op homself wat 'weet'. Die soek en tas kan hy nou aan die 'kroegman, klerk en predikant' en aan die profeet oorlaat; wat homself betref, is hy seker. Op grond van inligting wat hy as ingewyde kry, dat 'n wolk sou oopskeur en 'n vonk uitskiet, meen hy om tot God deur te dring en die troos te verkry dat God wag. God word die voorwerp van die mens se verowerende uitreiking gemaak, maar op so 'n manier kan geen verhouding met Hom tot stand kom nie. Waar die ' $U$ ' nagelaat word en die 'Hy' in sy plek kom, tree die mens buite die verhouding.

In 'n gedig met die tekenende titel 'Eengesprek' spreek hy 'n ' $U$ ' aan en vra of Hy Hom aan mense se lief en leed sou steur: 
hoor U ook soms ons volkies sing

van vreugdes wat die liefde bring;

van al die weë van die smart

en elke roering van die hart?

(Eengesprek, 1985:60)

Sou Hy weet van die onreg wat gepleeg word en die verdrukkers ken; die mense voor wie die volkies:

kan 'skiesbaas' skree met elke fluit

en sweepslag van sy dun sambok?

(Eengesprek, 1985:61)

Dat die digter hierdie vrae in 'n 'eengesprek' stel, gee te kenne dat hy nie 'n antwoord op sy vrae gekry het nie.

In sy ontmoeting met God sal die aard van die mens se gedrag ook belangrik wees. Anders as met eerbied en ontsag kan ons Hom nie tegemoet gaan nie. Maar by hierdie brug tussen God en mens het die digter verbygegaan en wend hy hom tot geweld. Hy maak oorlog teen God:

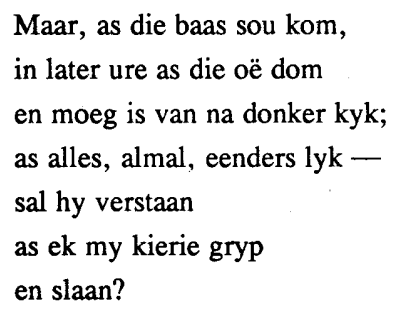

(Bedenking, 1985:62)

Die digter besef dat hy met sy verontagsaming van die eerbied en ootmoed, 'n gestelde grens oorskrei het en die verhouding tussen hom en die Ander geskaad het, want hy het sy bedenking of die Ander sal verstaan. Dat die Here kom soos Hy wil en wanneer Hy wil, is vir hom onaanvaarbaar. Hy voel te nagekom en neem sy toevlug tot geweld om op so 'n drastiese manier sy eie wil te laat geld. Die dreigement om met sy kierie te 
slaan, verwoord die weerstand wat die digter daarteen bied dat God teenoor hom op die wyse God kan wees, soos Hy dit self verkies. Hy wil God nie 'n kans gee om hom, die mens, te bevraagteken nie. Hy wil nie onseker gemaak word oor of hy oor homself beskik nie.

\section{SLOTOPMERKINGS}

Hierdie uitleg sou kan help om duidelik te mak wat in die menselewe op die spel is, of liewer, hoe die menselewe self op die spel is. Dit kan ook vir diegene wat reeds van die Christelike waarheid oortuig is, goed doen om opnuut te besef dat 'n mens eintlik nie anders na God kan roep as vanuit die dieptes nie. In hierdie tekste word deurgedring tot op die koue bodem van die menslike bestaan. Die koue moet nie as louheid of onbeslistheid gesien word nie, maar gee uitdrukking aan die afstand wat die mens tussen hom en God wil handhaaf. Maar hoe verder die mens self meen dat hy van God af is, hoe nader is hy in werklikheid aan Hom. En uit die hartstog waarmee Du Plessis die woord voer, is dit aanvoelbaar dat die vraag na homself en na God, vir hom nie 'n teoretiese aangeleentheid is nie, maar 'n lewensvraag. Die diepte waarin hy hom bevind, was vir hom werklik 'n kwelling. Uit die oogpunt van die Christelike verkondiging kom die ergste uitsigloosheid ook die naaste aan die aanvaarding van die heilsboodskap. Vir die geloof is die oorwegings en moontlikhede van die ongeloof nie vreemd nie. Die ervarings van die ongeloof sorg vir die beweging waarsonder 'n mens nie tot geloof sou kan deurdring nie. Die Ou en Nuwe Testament ken ook nie 'n ander geloof nie. Die God van wie die aanvegting kom, is ook die bron van die mens se vertroue dat $\mathrm{Hy}$ alles ten goede sal laat meewerk. So 'n vertroue in die Here verdiep die diepte waarin die mens hom bevind, nog verder deurdat hy leer om homself as die bron van sy ellende te sien en vra van hom om nie op homself en sy eie werke te vertrou, dat dit die lewe aan hom kan gee nie. Dit lei tot die nuwe ontdekking van die evangelie. Die gelowige sug en kla saam met die ongelowige, maar nie op dieselfde wyse nie. Sy klagte is nie hopeloos nie, maar kom uit 'n geduldige verwagting. Die gang deur hierdie tekste onderstreep die ou insig dat geloof nie 'n algemene moontlikheid is nie, maar net dan moontlik word wanneer dit geskied; dit wil sê, waar 'n mens die reddende mag van God se ontferming erken. Anders as binne 'n verhouding kan hierdie erkenning nie kom nie. En die verhouding bring God tot stand deur die verkondiging van sy woord, waardeur Hy Homself aan die mens toesê en die verbintenis met die mens stig. In die woord deel Hy Homself mee en laat die mens besef dat hy nie van hier is nie, maar dat God gedagtes van vrede oor hom het. As werklike sprekende woord spreek dit die werklikheid van die genade van God uit. Die uitspreek van hierdie werklikheid bring dit wat gesê word, ook tot stand. Selfs waar die mens tot 
die besef kom dat hy van voor sy geboorte af begenadig is (vgl Gal 1:15), kan die ontferming nie losgemaak word van die kommunikasie daarvan nie. In die kerklike verkondiging behoort geloof nie as iets vanselfsprekend of as 'n beskrywing van 'n toestand beskou te word nie, maar moet die evangelie gebring word as die oorgang van die ou na die nuwe verstaan van die mens en die wêreld en God. Die lewe in so 'n geloof het sy eie kontinuïteit in die sin dat die gelowige homself uit die hand van God ontvang en homself aanvaar. Sy ware self gee aan sy lewe verloop en kontinuiteit.

Ten slotte moet daarop gewys word dat ongeloof nie 'n tweede, 'n gelykberegtigde moontlikheid van lewe naas die geloof is nie. Die ongeloof tree na vore as 'n onmoontlikheid of 'n moontlikheid wat tot ondergang lei. Nie die hoop is 'n verduideliking verskuldig nie, maar die wanhoop:

Die nag is net toe deure, gegrendel en gesluit, en hoop klop soveel kere, maar die stilte hou hom uit ... ek wéét.

(Herbergier, 1988:63)

\section{Literatuurverwysings}

Du Plessis, K (1981) 1988. Kinders van die wind en ander lirieke met wysies en akkoorde. Ingelei deur Hennie Aucamp. Eerste sagtebanduitgawe, tweede druk. Kaapstad: Tafelberg.

1985. Om jou verlaas te groet: Nagelate verse. Kaapstad: Human \& Rousseau.

1990. Die musiek van Koos du Plessis: Die bladmusiek, lirieke en kitaarakkoorde van 18 van sy gewildste liedjies. Johannesburg: Perskor. (Musiek S A)

Kierkegaard, S [1849] 1911. Die Krankheit zum Tode. Übersetzt und mit Nachwort von H Gottsched. Jena: Diederichs. (Gesammelte Werke 8.) 